Kelola

\title{
SUPERVISI PENDIDIKAN OLEH PENGAWAS SEKOLAH ${ }^{1}$
}

\author{
Slameto \\ Program Pascasarjana Magister Manajemen Pendidikan \\ FKIP-Universitas Kristen Satya Wacana \\ slameto@staff.uksw.edu
}

\begin{abstract}
The problem in this research was related to the effectiveness of supervision programs implemented by the school superintendent and formulated by: 1) What were the steps supervision was conducted by a school supervisor? 2) How were the results of supervision for teachers in improving the quality of education? 3) What were the constraints and any supporting factors faced by school inspectors in carrying out its duties and functions? This study used a study document on the results of previous studies. The data collected by searching through Google Scholar journal. From the search results obtained by 26 then selected to obtain 9 journals which fill in criteria needed. From these 9 journals then conducted a meta-analysis. The results related to measures of supervision performed by school inspectors programmed, structured attention to the vision, mission and goals of partner schools and their regulations: include academic supervision carried out by applying the techniques of individuals and groups. Evaluation results were obtained surveillance program varies, ranging from moderate to attribute positive results. Evaluation of the implementation of supervision was ranged from the low category to very well performance. The evaluations toward the result supervision were also varying from low category, moderate to perform effectively. Constraints faced by school inspectors in carrying out their duties and functions to be involved in external conditions and internal inspectors concerned.
\end{abstract}

Keywords: Supervision, supervision programs, the results and impact of supervision, obstacles faced by school inspectors

\section{PENDAHULUAN}

Di dunia pendidikan Indonesia, diterapkannya secara formal konsep supervisi diperkirakan sejak diberlakukannya Keputusan Menteri P dan K, RI. Nomor: 0134/1977, yang menyebutkan siapa saja yang berhak disebut supervisor di sekolah, yaitu kepala sekolah, penilik sekolah untuk tingkat kecamatan, dan para pengawas di tingkat kabupaten/ Kotamadya serta staf kantor bidang yang ada di setiap propinsi. Di dalam PP Nomor 38/Tahun 1992, terdapat perubahan penggunaan istilah pengawas dan

\footnotetext{
${ }^{1}$ Naskah ini telah disajikan dalam Seminar Nasional dan Musyawarah Kerja ke V, Asosiasi Program Studi MP/AP/MPI Indonesia, dengan tema "Standarisasi KKNI Program Studi MP/AP dalam rangka Peningkatan Kompetensi Kepala/ Pengawas Sekolah di Era Masyarakat Ekonomi ASEAN", JumatMinggu, 11-13 Nopember 2016 di Bengkulu.
} 
penilik. Istilah pengawas dikhususkan untuk supervisor pendidikan di sekolah sedangkan penilik khusus untuk pendidikan luar sekolah.

Standar mutu pengawas yang telah ditetapkan oleh Direktorat Jenderal Peningkatan Mutu Pendidik dan Tenaga Kependidikan Direktorat Tenaga Kependidikan Departemen Pendidikan Nasional (Sudjana, Nana, 2006) bahwa pengawas sekolah berfungsi sebagai supervisor baik supervisor akademik maupun supervisor manajerial. Sebagai supervisor akademik, pengawas sekolah berkewajiban untuk membantu kemampuan profesional guru agar guru dapat meningkatkan mutu proses pembelajaran. Sedangkan sebagai supervisor manajerial, pengawas berkewajiban membantu kepala sekolah agar mencapai sekolah yang efektif. Pembinaan dan pengawasan kedua aspek tersebut hendaknya menjadi tugas pokok pengawas sekolah. Semua produk hukum itu mengarahkan bahwa kedudukan pengawas bukan hanya sebagai jabatan buangan dan pajangan di kantor dinas pendidikan, tetapi mempunyai fungsi penggerak kemajuan pendidikan di sekolah. Sebagaimana guru, pengawas juga harus memulai pekerjaan dengan perencanaan, pelaksanaan dan diakhir dengan pelaporan (Aripin. 2011; Imam Gazali, 2011).

Sesuai dengan perkembangan masyarakat dan perkembangan pendidikan di negara kita Indonesia, sejak zaman penjajahan Belanda hingga zaman kemerdekaan sampai sekarang, kewajiban dan tanggungjawab para pemimpin pendidikan pada umumnya dan kepala sekolah pada khususnya mengalami perkembangan dan perubahan pula. Adapun perubahan-perubahan tersebut dapat dibagi menjadi tiga aspek: 1) perubahan dalam tujuan, 2) perubahan dan scope (luasnya tanggung-jawab/ kewajiban), dan 3) perubahan dalam sifatnya (Hardja Sapoetra. 2010). Ketiga aspek tersebut sangat berhubungan erat dan sukar untuk dipisahkan satu dengan lainnya. Adanya perubahan dalam tujuan pendidikan, mengubah pula scope atau luasnya tanggungjawab yang harus dipikul dan dilaksanakan oleh para pemimpin pendidikan. Hal ini merubah pula bagaimana sifat-sifat kepemimpinan yang harus dijalankan hingga dapat mencapai tujuan yang telah ditetapkan.

Tugas supervisor adalah menstimulir guru-guru agar mempunyai keinginan menyelesaikan problema pengajaran dan mengembangkan kurikulum. Mengidentifikasikan kebutuhan guru-guru sebagai bahan in-service dan survei sebagai permintaan dan observasi. Merencanakan langkah-langkah pelaksanaan dan mengevaluasi in-service program, dengan mengembangkan rencana pengajaran untuk pengembangan staf membuat komponen-komponen pengetahuan, fasilitas yang digunakan. Kemudian mencatat partisipasi guru-guru dan sukses keberhasilan inservice. Oleh karena itu tugas besar bagi pemimpin pengajaran adalah merubah guruguru dari 'apatis menjadi dinamis", dari tidak mampu menjadi berkemampuan, dari tidak peduli menjadi peduli, dari yang sembrono menjadi cermat, kritis, dan mengerti tugas-tugasnya sebagai guru (Sagala, 2000).

Roland Barth menyatakan bahwa kebutuhan interaksi dengan guru lebih mendorong pertumbuhan, ia mengidentifikasikan guru dalam tiga kelompok, yaitu: 
1. Guru-guru yang tidak mampu mempelajari secara kritis praktek mengajar, orang tua murid, dan lainnya tidak peduli terhadap apa dan bagaimana mereka mengajar;

2. Guru-guru yang memiliki kemampuan meneliti secara berkesinambungan menunjukkan apa yang mereka kerjakan dengan menggunakannya untuk melakukan perubahan;

3. Sedikit guru yang mau dan mampu meneliti secara cermat dan kritis praktek mereka sendiri dan orang lain mengenai kemampuan mereka dan memberikan penilaian baik terhadap apa yang mereka kerjakan (Mintarsih Danumihardja, 2009).

Program supervisi biasanya berisikan kegiatan yang akan dijalankan untuk memperbaiki kinerja guru dalam meningkatkan situasi pembelajaran yang menjadi tanggung jawabnya. Di dalam program supervisi tertuang berbagai usaha dan tindakan yang perlu dijalankan supaya pembelajaran menjadi lebih baik, sehingga akselerasi belajar peserta didik makin cepat dalam mengembangkan potensi dirinya, karena guru lebih mampu mengajar. Program supervisi akademik menurut Djam'an Satori (1997) “... dimaksudkan untuk memperbaiki dan meningkatkan proses dan hasil belajar mengajar ... supaya kegiatan pembinaan relevan dengan peningkatan kemampuan profesional guru."

Program supervisi harus realistik dan dapat dilaksanakan sehingga benar-benar membantu mempertinggi kinerja guru. Program supervisi yang baik menurut Oteng Sutisna (1983) mencakup keseluruhan proses pembelajaran yang membangun lingkungan belajar mengajar yang kondusif, di dalamnya mencakup maksud dan tujuan, pengembangan kurikulum, metode mengajar, evaluasi, pengembangan pengalaman belajar murid yang direncanakan baik dalam intra maupun extra kurikuler (Bang Mohtar, 2012).

Program supervisi berprinsip kepada proses pembinaan guru yang menyediakan motivasi yang kaya bagi pertumbuhan kemampuan profesionalnya dalam mengajar. Ia menjadi bagian integral dalam upaya peningkatan mutu sekolah, mendapat dukungan semua pihak disertai dana dan fasilitasnya. Bukan sebuah kegiatan suplemen atau tambahan (Suhardan, 2010; Ruzi Rahmawati, 2012).

Setiap bidang kegiatan memerlukan perencanaan yang sistemik dan prospektif untuk mencapai tujuan secara efektif. Supervisi merupakan usaha untuk mendorong para guru mengembangkan kemampuannya agar dapat mencapai tujuan pendidikan secara efektif. Oleh karena itu, dalam supervisi, perencanaan merupakan kegiatan yang perlu dilakukan sebaik-baiknya. Tanpa perencanaan yang baik supervisi hanya memberikan kekecewaan kepada pihak-pihak yang terlibat di dalamnya, yaitu guru, kepala sekolah, supervisor dan terutama murid- murid yang mengharapkan pembelajaran dapat berlangsung secara aktif, efektif, kreatif, dan menyenangkan (Masaong, 2013).

Sebagai gurunya guru, pengawas harus menyusun rencana untuk memperkuat implementasi keempat kompetensi guru, yaitu kompetensi pedagogik, kompetensi kepribadian, kompetensi sosial dan kompetensi profesional. Oleh karena itu, pengawas dituntut memiliki visi dan misi kepengawasan yang mampu dituangkan ke dalam tujuan 
dan strategi pencapaiannya. Kekurangefektifan pelaksanaan supervisi selama ini karena ditengarai kurang jelasnya visi dan misi kepengawasan yang dilakukan oleh pengawas. Pelaksanaan supervisi pun terkesan asal dilaksanakan dan tidak mengacu pada kebutuhan guru sehingga menimbulkan kurangnya kepercayaan guru terhadap pengawas untuk menyelesaikan problematika pembelajaran. Program supervisi harus mengacu pada visi, misi, tujuan dan strategi pembinaan ditetapkan oleh pengawas. Keterlibatan guru dan kepala sekolah dalam penyusunan rencana kerja pengawas sangat efektif dalam meningkatkan kompetensi profesional guru dan kemampuan manajerial kepala sekolah (Masaong, 2013).

Rencana kerja pengawas yang berkaitan dengan supervisi manajerial dituntut mengacu pada aspek fungsi dan substansi manajemen sekolah. Aspek fungsi manajemen mencakup perencanaan, pengorganisasian, pengkoordinasian, pengendalian, monitoring dan evaluasi serta pelaporan. Sedangkan aspek substansi manajerial sekolah mencakup pengelolaan kurikulum dan pembelajaran, pengelolaan ketenagaan, pengelolaan kesiswaan, pengelolaan keuangan dan pembiayaan sekolah, pengelolaan sarana dan prasarana sekolah serta pengelolaan hubungan sekolah dengan masyarakat. Pengawas dituntut memiliki pengetahuan yang mumpuni dalam memandang manajemen sekolah sebagai satu kesatuan sistem yang di dalamnya berpadu antara aspek fungsi dan substansi manajerial. Keefektifan pelaksanaan substansi manajemen di sekolah tergantung pada kemampuan kepala sekolah menerapkan fungsi-fungsi manajemen mulai dari perencanaan sampai pada pelaporan sebagaimana terlihat pada figur di halaman berikut. Tugas pengawas untuk membantu kepala sekolah dalam menyusun visi dan misi sekolah binaan sampai dituangkan dalam rencana kerja sekolah sangat dibutuhkan.

Terdapat beberapa aspek yang perlu menjadi prioritas dalam penyusunan program supervisi manajerial menuju sekolah efektif, yaitu: a). Kepemimpinan yang profesional, b) Fokus pada kualitas pembelajaran, c) Keefektifan pencapaian indikator pembelajaran, d) Berorientasi pada visi, misi dan tujuan sekolah, e) Harapan yang tinggi bagi semua peserta didik, f) Akuntabilitas pengelolaan sekolah, g) Penciptaan masyarakat belajar bagi warga sekolah, h) Stimulasi/dukungan lingkungan sekolah (Creemers dalam Masaong, 2013). Rivai (1981) mengemukakan beberapa karakteristik perencanaan supervisi sebagai berikut: (1) supervisi tidak ada rencana yang standar, (2) perencanaan supervisi memerlukan kreativitas, (3) komprehensif, (4) kooperatif, dan (5) fleksibel.

Berbagai pengetahuan dan keterampilan diperlukan dalam penyusunan rencana supervisi yang efektif. Faktor mana yang lebih diperlukan, tergantung dari situasi, kondisi tempat menyusun rencana itu, dan tujuan yang akan dicapai. Tiap supervisor harus menyadari kedudukannya, apakah sebagai kepala sekolah, sebagai penilik/ pengawas, atau sebagai pemegang otoritas administratif. Ia harus dapat menentukan faktor mana yang lebih diperlukan untuk menyusun rencana yang sesuai dengan situasi dan tujuan yang ingin dicapainya. 
Peter F. Olivia (1984) mengemukakan sasaran domain supervisi pengajaran adalah hubungan pengembangan staf dengan in-service education, perbedaan pengembangan staf dengan in-service education, asumsi pentingnya in-service education, tiga supervisor dalam in-service education, kelemahan in-service education, ciri-ciri in-service education, dan mengenai mengontrol in-service education. In-service education bagian dari pengembangan staf yang dibagi dalam dua kategori yang staffing yang terdiri dari kegiatan selecting, assigning, evaluating, reticing, dismissing staf, dan trainin (Mintarsih Danumihardja, 2009).

Pada dasarnya supervisi adalah program yang berencana untuk memperbaiki pengajaran. Program itu pada hakikatnya adalah perbaikan hal belajar mengajar. Dalam melaksanakan supervisi, pengawas sekolah pasti menghadapi kendala-kendala. Hal ini sesuai dengan yang telah disampaikan oleh Direktorat Tenaga Kependidikan Dirjen Peningkatan Mutu Pendidik dan Tenaga Kependidikan Departemen Pendidikan Nasional (2007), "Para kepala sekolah dan atau pengawas baik suka maupun tidak suka harus siap menghadapi problema dan kendala dalam melaksanakan supervisi pendidikan". Kendala supervisi pendidikan yang sangat umum terjadi di lapangan adalah kurangnya motivasi dari para guru ketika mendapat supervisi. Hal tersebut terjadi dikarenakan adanya anggapan yang telah melekat dalam diri guru bahwa supervisi hanyalah kegiatan yang semata-mata untuk mencari-cari kesalahan.

Berdasarkan paparan di atas, menarik untuk menkaji tentang efektifitas program supervisi yang dilaksanakan oleh pengawas sekolah; rumusan masalah dalam kajian ini adalah: 1) langkah supervisi apakah yang dilakukan oleh pengawas sekolah? 2) bagaimana hasil pengawasan bagi guru dalam peningkatan mutu pendidikan, 3) kendala dan faktor pendukung apa saja yang dihadapi pengawas sekolah dalam melaksanakan tugas dan fungsinya?

\section{METODE PENELITIAN}

Penelitian ini menggunakan studi dokumen atas hasil-hasil penelitian sebelumnya. Pengumpulan data dalam penelitian ini dilakukan dengan menelusuri jurnal pada beberapa media elektronik seperti digital library, internet, maupun koleksi jurnal perpustakaan. Penelusuran jurnal dilakukan melalui Google Cendekia. Kata kunci yang digunakan untuk penelusuran jurnal adalah: "supervisi oleh pengawas sekolah" dan "hasil penelitian". Dari hasil penelusuran diperoleh 26, dipilih yang memenuhi kriteria yaitu tersedianya data 1) langkah supervisi yang dilakukan oleh pengawas sekolah? 2) hasil pengawasan bagi guru dalam peningkatan mutu pendidikan, 3) kendala dan faktor pendukung yang dihadapi pengawas sekolah dalam melaksanakan tugas dan fungsinya. setelah diseleksi diperoleh 9 hasil penelitian. Sesuai urutan tahun terbitnya 9 hasil penelitian tersebut adalah sebagai berikut:

1. Makmurrizal, Cut Zahri Harun, dan Sakdiah Ibrahim, 2016. Pelaksanaan Supervisi oleh Pengawas Sekolah dalam Meningkatkan Kompetensi Rofesionalisme Guru pada SMA Negeri 2 Bandar Baru Pidie Jaya

2. Ahmad Ihsanuddin, 2015, Implementasi Supervisi Pengawas PAI dalam Meningkatkan Kompetensi Pedagogik Guru PAI SD di Kecamatan Berbah Sleman 
3. Diaz Wiryawan, 2015. Kontribusi Partisipasi Guru Dalam Kelompok Kerja Guru (KKG) dan Intensitas Supervisi Akademik oleh Pengawas Terhadap Kinerja Guru Sekolah Dasar Se-Kecamatan Kotagede Yogyakarta

4. Shokhikhah, N. I., \& PD, S. 2015. Pelaksanaan Supervisi Akademik Terhadap Guru Bahasa Arab (Studi Kasus di MTs Negeri Parakan Temanggung)

5. Dewi Novrita, 2014. Maksimalisasi Peran Pengawas Sekolah Menengah Atas Dalam Meningkatkan Profesionalisme Guru PAI Studi Kasus Pada Kementerian Agama di Kota Jayapura, Papua

6. Julkarnain Syawal, Badrun Kartowagiran, 2013. Evaluasi Kinerja Pengawas Sekolah Dalam Melakukan Supervisi Penyelenggaraan Pendidikan SD di Kota Tidore Kepulauan

7. Latifa Saleh, 2013. Evaluasi Program Pengawas di SDN Se Kecamatan Telaga Biru Kabupaten Gorontalo.

8. Rachmat Suliadi, 2009. Hubungan Antara Supervisi Pengawas Sekolah, Inten-sitas Kegiatan MGMP dan Motivasi Berprestasi Guru dengan Profesi-nalisme Guru SMA Negeri di Kota Malang

9. Nur Muhammad, 1988. Manajemen Pengawas dalam Pelaksanaan Supervisi Pendidikan Pada PAUD di Kota Banda Aceh.

Dari ke 9 hasil penelitian itu selanjutnya dilakukan Meta Analisis.

\section{HASIL PENELITIAN}

Berdasarkan studi 9 hasil penelitian seperti di atas, dapat dirangkum dalam 3 tabel berikut ini.

\section{Tabel 1}

\section{Langkah supervisi yang dilakukan oleh pengawas sekolah}

\begin{tabular}{|c|l|}
\hline No & Langkah supervisi yang dilakukan oleh pengawas sekolah \\
\hline 1 & $\begin{array}{l}\text { Pelaksanaan supervisi yang dilaksanakan pengawas sekolah belum terprogram, } \\
\text { sehingga pengawas sekolah belum sepenuhnya dapat meningkatkan profesionalisme } \\
\text { guru; } \\
\text { Teknik supervisi yang dilaksanakan pengawas adalah dengan diskusi kelompok, } \\
\text { mengadakan kunjungan kelas, pembicaraan individual. Semua inibersifat umum } \\
\text { sekadar hanya menjalankan tugas dan belum ke arah peningkatan profesionalisme guru. } \\
\text { Pelaksanaan supervisi dilakukan pengawas secara singkat, karena keterbatasan waktu. } \\
\text { Selain itu, pengawas belum membuat perencanaan yang lebih baik; }\end{array}$ \\
\hline 2 & Na \\
\hline 3 & Na \\
\hline 4 & $\begin{array}{l}\text { Pelaksanaan supervisi akademik di MTs N Parakan dilakukan oleh pengawas dan } \\
\text { kepala madrasah. Pelaksanaan supervisi akademik kepala madrasah dilakukan dengan } \\
\text { membentuk tim sembilan. Teknik yang digunakan supervisor berupa teknik individual }\end{array}$ \\
& $\begin{array}{l}\text { yang meliputi: (a) kunjungan dan observasi kelas, (b) pertemuan/percakapan individual, } \\
\text { dan teknik kelompok yang digunakan adalah mengikutsertakan guruguru dalam } \\
\text { MGMP, workshop, diklat, seminar, dan rapat guru. Supervisi akademik pengawas } \\
\text { dilakukan dengan teknik pertemuan kelompok. } \\
\text { 2) Pelaksanaan supervisi akademik terhadap guru bahasa Arab di MTs N Parakan } \\
\text { meliputi tahap persiapan, pelaksanaan, dan penilaian/pelaporan. } \\
\text { 3) Pelaksanaan supervisi pengawas terhadap guru bahasa Arab lebih mengarah pada } \\
\text { pembinaan. Jenis kegiatan dalam pembinaan supervisi akademik adalah pembuatan } \\
\text { program, pelaksanaan program, penilaian/pelaporan, dan rencana tindak lanjut. }\end{array}$ \\
\hline
\end{tabular}




\begin{tabular}{|c|c|}
\hline & $\begin{array}{l}\text { Pada tahap penilaian, pengawas tidak menggunakan instrumen yang telah } \\
\text { direncanakan, penilaian yang dilakukan secara langsung. } \\
\text { Langkah lain yang digunakan untuk meningkatkan kompetensi guru bahasa Arab yaitu } \\
\text { dengan mengikutsertakan guru bahasa Arab dalam kegiatan MGMP, workshop, diklat, } \\
\text { dan seminar-seminar. }\end{array}$ \\
\hline 5 & $\mathrm{Na}$ \\
\hline 6 & $\begin{array}{l}\text { Penyusunan program pengawasan memperoleh skor nilai } 76,5 \text { atau berprestasi baik, } \\
\text { Pelaksanaan program pengawasan memperoleh skor nilai } 95 \text { atau berprestasi amat baik, } \\
\text { Pelaksanaan evaluasi hasil pelaksanaan program pengawasan memperoleh skor nilai } 55 \\
\text { atau berprestasi sedang, } \\
\begin{array}{l}\text { Pelaksanaan pembimbingan dan pelatihan profesional guru dan kepala sekolah } \\
\text { berprestasi cukup, dengan skor nilai } 62,5 \text {. }\end{array}\end{array}$ \\
\hline 7 & $\begin{array}{l}\text { Evaluasi penyusunan program pengawas dilaksanakan sangat efektif sesuai dengan } \\
\text { perencanaan program supervisi sebagaimana terlampir pada program kerja pengawas } \\
\text { yakni melakukan pengawasn setiap semesteran, triwulan dan bulanan } \\
\text { Evaluasi pelaksanaan program oleh pengawasan di Kecamatan Telaga Biru sudah } \\
\text { dilaksanakan secara baik sesuai dengan aturan dan pedoman yang ada setiap pengawas, } \\
\text { Evaluasi pembimbingan dan pelatihan yang dilakukan oleh pengawas ternyata } \\
\text { menujukan hasil yang positif dari pihak sekolah, guru maupun siswa. }\end{array}$ \\
\hline 8 & $\mathrm{Na}$ \\
\hline 9 & $\begin{array}{l}\text { Perencanaan program kerja pengawas PAUD, disusun berdasarkan visi, misi dan tujuan } \\
\text { pengawas PAUD melalui kegiatan supervisi akademik dan supervisi manajerial pada } \\
\text { PAUD binaan, yang diarahkan untuk meningkatkan kemampuan pengawas sesuai } \\
\text { dengan kompetensinya. } \\
\text { Pelaksanaan kegiatan pengawasan PAUD, sesuai dengan ketentuan supervisi akademik } \\
\text { dan manajerial. Kegiatan supervisi akademik dilakukan untuk membantu guru dalam } \\
\text { mengelola pembelajaran sedangkan supervisi manajerial dilakukan untuk membantu } \\
\text { kepala PAUD dalam kegiatan manajerial. } \\
\text { Evaluasi program supervisi PAUD dilakukan oleh Koordinator Pengawas Dinas } \\
\text { Pendidikan Pemuda dan Olahraga Kota Banda Aceh. Hasil penilaian secara khusus } \\
\text { dituangkan dalam DP3 (Daftar Penilaian Pekerjaan Pegawai). Penilaian dilakukan } \\
\text { berdasarkan hasil kerja pengawas dalam melaksanakan tugasnya meliputi kesetiaan, } \\
\text { prestasi kerja, tanggung jawab, ketaaatan, kejujuran, kerja sama, prakarsa dan } \\
\text { kepemimpinan. }\end{array}$ \\
\hline
\end{tabular}

Berdasarkan temuan pelaksanaan pengawasan oleh pengawas sekolah seperti tersaji pada tabel 1 di atas, ternyata ada 2 versi pengawas melaksanakan pengawasan terhadap sekolah binaan baik terhadap kepala sekolah maupun guru: tidak terprogram [1] dan telah terprogram [4, 6, 7, 9]. Jika pengawas dalam melaksanakan supervisinya belum menyusun program, sangatlah wajar bila pengawas sekolah belum sepenuhnya dapat meningkatkan mutu sekolah termasuk profesionalisme kepala sekolah dan guru [1]. Program supervisi terdiri dari perencanaan, pelaksanaan dan evaluasi. Dari hasil penelitian ternyata belum ada program tindak lanjut yang dirancang oleh pengawas.

Dalam menyusun program supervisi bagi sekolah binaan, terdapat pengawas yang menyusun program bekerja sama dengan kepala sekolah binaan [4, 9]; dengan demikian akan terdapat variasi program supervisi pengawas di sekolah satu dengan yang lainnya. Program supervisi yang disusun memperhatikan visi, misi dan tujuan sekolah binaan. Dalam penyusunan program supervisi, para pengawas mendasarkan Peraturan Menteri Pendidikan Nasional Republik Indonesia Nomor 12 Tahun 2007. Program supervisi terdiri dari 2 komponen, yaitu supervisi akademik/pengajaran dan 
supervisi manajejerial $[4,6,7,9]$; bahkan disamping itu ada pengawas yang melakukan pembimbingan dan pelatihan profesional guru dan kepala sekolah berprestasi [6].

Pelaksanaan supervisi oleh pengawas sekolah mendasarkan prencanaan/ program yang telah disusun; meliputi tahap: persiapan, pelaksanaan, dan penilaian/ pelaporan [4]; sudah dilaksanakan secara baik sesuai dengan aturan dan pedoman yang ada, dan lebih mengarah pada pembinaan [4]. Jenis kegiatan dalam pembinaan supervisi akademik adalah pembuatan program, pelaksanaan program, penilaian/ pelaporan, dan rencana tindak lanjut. Kegiatan supervisi akademik dilakukan untuk membantu guru dalam mengelola pembelajaran sedangkan supervisi manajerial dilakukan untuk membantu kepala sekolah dalam kegiatan manajerial [9];

Teknik yang digunakan pengawas sekolah dalam mensupervisi sekolah berupa teknik individual dan teknik kelompok. Teknik individu yang meliputi: (a) kunjungan dan observasi kelas, (b) pertemuan/percakapan individual. Teknik kelompok meliputi: diskusi kelompok, mengadakan kunjungan kelas, mengikutsertakan guru-guru dalam MGMP, workshop, diklat, seminar, dan rapat guru. Semua ini terkesan bersifat umum sekadar hanya menjalankan tugas dan belum ke arah peningkatan profesionalisme guru. Pelaksanaan supervisi dilakukan pengawas secara singkat, karena keterbatasan waktu. Selain itu, pengawas belum membuat perencanaan yang lebih baik [1].

Evaluasi program pengawasan memperoleh skor nilai 55 atau berprestasi sedang [6]; Evaluasi pembimbingan dan pelatihan yang dilakukan oleh pengawas ternyata menujukan hasil yang positif dari pihak sekolah, guru maupun siswa [7]. Evaluasi program supervisi dilakukan oleh Koordinator Pengawas Dinas Pendidikan Pemuda dan Olahraga Kota. Hasil penilaian secara khusus dituangkan dalam DP3 (Daftar Penilaian Pekerjaan Pegawai). Penilaian dilakukan berdasarkan hasil kerja pengawas dalam melaksanakan tugasnya meliputi kesetiaan, prestasi kerja, tanggung jawab, ketaaatan, kejujuran, kerja sama, prakarsa dan kepemimpinan [9]. Terdapat satu hasil penelitian yang menyatakan bahwa pengawas sekolah tidak menggunakan instrumen dalam tahap penilaiannya, penilaian yang dilakukan secara langsung [4]; apapun alasanya, bisa diduga kualitas profesionalitas pengawasnya, serta bagaimana mutu sekolah hasil binaannya.

Hasil pengawasan bagi guru dalam peningkatan mutu pendidikan tersaji dalam tabel 2 berikut ini.

Tabel 2

Hasil pengawasan bagi guru dalam peningkatan mutu pendidikan

\begin{tabular}{|c|l|}
\hline No & Hasil pengawasan bagi guru dalam peningkatan mutu pendidikan \\
\hline 1 & $\begin{array}{l}\text { Pelaksanaan supervisi yang dilaksanakan pengawas sekolah belum terprogram, } \\
\text { sehingga pengawas sekolah belum sepenuhnya dapat meningkatkan profesionalisme } \\
\text { guru; }\end{array}$ \\
\hline 2 & $\begin{array}{l}\text { Supervisi yang dilakukan pengawas Pendidikan Agama Islam cukup efektif dalam } \\
\text { meningkatkan Kompetensi pedagogik guru PAI terlihat dari meningkatnya } \\
\text { penguasaan guru terhadap teori belajar dan prinsip pembelajaran, efektivitas guru } \\
\text { dalam pembelajaran yang mendidik, dan fasilitasi pengembangan potensi peserta } \\
\text { didik. }\end{array}$ \\
\hline
\end{tabular}




\begin{tabular}{|c|c|}
\hline 3 & $\begin{array}{l}\text { Kontribusi intensitas supervisi oleh pengawas terhadap kinerja Guru Sekolah } \\
\text { Dasar se-Kecamatan Kotagede Yogyakarta sebesar 25,8\%. Hal ini ditunjukkan } \\
\text { dari nilai koefisien determinasi sebesar 0,258, dengan koefisien thitung sebesar } \\
6,098 \text { pada taraf signifikan 5\%. }\end{array}$ \\
\hline 4 & $\begin{array}{l}\text { Penilaian hasil supervisi akademik, menunjukkan bahwa guru bahasa Arab dapat } \\
\text { dikatakan profesional karena hasil nilai empat guru bahasa Arab berada pada } \\
\text { kategori baik }\end{array}$ \\
\hline 5 & $\begin{array}{l}\text { Kinerja pengawas sekolah di lingkungan Kementerian Agama di Kota Jayapura } \\
\text { masih belum maksimal karena perbandingan antara banyaknya sekolah yang harus } \\
\text { diawasi dengan jumlah pengawas tidak seimbang. Dalam kasus di Kota Jayapura, } \\
\text { satu orang pengawas harus melakukan pengawasan terhadap } 16 \text { Sekolah Menengah } \\
\text { Atas sehingga kinerjanya kurang maksimal. }\end{array}$ \\
\hline 6 & $\begin{array}{l}\text { Penyusunan program pengawasan memperoleh skor nilai } 76,5 \text { atau berprestasi baik, } \\
\text { Pelaksanaan program pengawasan memperoleh skor nilai } 95 \text { atau berprestasi amat } \\
\text { baik, } \\
\text { Pelaksanaan evaluasi hasil pelaksanaan program pengawasan memperoleh skor nilai } \\
55 \text { atau berprestasi sedang, } \\
\text { Pelaksanaan pembimbingan dan pelatihan profesional guru dan kepala sekolah } \\
\text { berprestasi cukup, dengan skor nilai } 62,5 \text {. }\end{array}$ \\
\hline 7 & $\begin{array}{l}\text { valuasi penyusunan program pengawas dilaksanakan sangat efektif sesuai dengan } \\
\text { rencanaan program supervisi sebagaimana terlampir pada program kerja } \\
\text { ngawas yakni melakukan pengawasn setiap semesteran, triwulan dan bulanan } \\
\text { valuasi pelaksanaan program oleh pengawasan di Kecamatan Telaga Biru sudah } \\
\text { laksanakan secara baik sesuai dengan aturan dan pedoman yang ada setiap } \\
\text { ngawas, namun masih terdapat beberapa kekurangan yang menjadi perhatian } \\
\text { num yakni pelaksanaan kunjugan ke sekolah belum sesuai dengan jadwal yang } \\
\text { lah ditetapkan. Evaluasi pelaksanaan program pengawas secara langsung belum } \\
\text { sa memenuhi standar evaluasi dan monitoring yang dilaksanakan oleh pengawas } \\
\text { iik secara periodik atau kontinyu sesuai dengan lembar kerja pengawas. } \\
\text { valuasi pembimbingan dan pelatihan yang dilakukan oleh pengawas ternyata } \\
\text { enujukan hasil yang positif dari pihak sekolah, guru maupun siswa. Pada pihak } \\
\text { kolah berdampak pada penataan administrasi, pihak guru terjadi peningkatan } \\
\text { ofesionalisasi dalam hal perencanaan, pelaksanaan serta evaluasi hasil belajar dan } \\
\text { swa nampak pada keberhasilan pada prestasi siswa semakin meningkat dari waktu } \\
\text { waktu. }\end{array}$ \\
\hline 8 & $\begin{array}{l}\text { Supervisi pengawas sekolah di kota Malang termasuk dalam kategori rendah, } \\
\text { walaupun begitu } \\
\text { Terdapat hubungan yang signifikan antara supervisi pengawas sekolah dengan } \\
\text { profesionalisme guru, }\end{array}$ \\
\hline 9 & $\begin{array}{l}\text { Pelaksanaan kegiatan pengawasan PAUD, sesuai dengan ketentuan supervisi } \\
\text { akademik dan manajerial. Kegiatan supervisi akademik dilakukan untuk membantu } \\
\text { guru dalam mengelola pembelajaran sedangkan supervisi manajerial dilakukan } \\
\text { untuk membantu kepala PAUD dalam kegiatan manajerial. } \\
\text { Penilaian dilakukan berdasarkan hasil kerja pengawas dalam melaksanakan } \\
\text { tugasnya meliputi kesetiaan, prestasi kerja, tanggung jawab, ketaaatan, kejujuran, }\end{array}$ \\
\hline
\end{tabular}

Evaluasi program supervisi menyangkut perencanaan $[1,6,7]$, pelaksanaan $[1,6,7,8,9]$ maupun hasil $[2,4,5,6,7]$, bahkan dampak program $[1,3,7,8,9]$. Evaluasi terhadap perencanaan supervisi (kecuali yang tidak menyusun program) adalah: penyusunan program pengawasan memperoleh skor nilai 76,5 atau baik [6], Evaluasi penyusunan program pengawas dilaksanakan sangat efektif sesuai dengan 
perencanaan program supervisi sebagaimana terlampir pada program kerja pengawas yakni melakukan pengawasan setiap semesteran, triwulan dan bulanan [7].

Evaluasi pelaksanaan supervisi adalah seperti nerikut ini: pelaksanaan supervisi yang dilaksanakan pengawas sekolah belum terprogram [1]. Bagi pengawas yang telah menyusun program, supervisi pengawas sekolah di kota Malang misalnya, termasuk dalam kategori rendah [8], pelaksanaan program pengawasan memperoleh skor nilai 95 atau berprestasi amat baik [6], sudah dilaksanakan secara baik sesuai dengan aturan dan pedoman yang ada setiap pengawas, (walau masih terdapat beberapa kekurangan yang menjadi perhatian umum yakni pelaksanaan kunjugan ke sekolah belum sesuai dengan jadwal yang telah ditetapkan, dan belum bisa memenuhi standar evaluasi dan monitoring yang dilaksanakan oleh pengawas baik secara periodik sesuai dengan lembar kerja pengawas) [7]. Pelaksanaan kegiatan pengawasan, sesuai dengan ketentuan supervisi akademik dan manajerial. Kegiatan supervisi akademik dilakukan untuk membantu guru dalam mengelola pembelajaran sedangkan supervisi manajerial dilakukan untuk membantu kepala dalam kegiatan manajerial [9].

Evaluasi terhadap hasil supervisi adalah seperti berikut ini: Kinerja pengawas sekolah di lingkungan Kementerian Agama di Kota Jayapura masih belum maksimal [5]; Supervisi pengawas sekolah di kota Malang termasuk dalam kategori rendah [8]; hasil pelaksanaan program pengawasan memperoleh skor nilai 55 atau berprestasi sedang [6]; meningkatnya kompetensi pedagogik guru terlihat dari meningkatnya penguasaan guru terhadap teori belajar dan prinsip pembelajaran, efektivitas guru dalam pembelajaran yang mendidik, dan fasilitasi pengembangan potensi peserta didik [2]; Hasil supervisi akademik, menunjukkan bahwa guru dapat dikatakan profesional karena hasil nilai empat guru berada pada kategori baik [4]. Evaluasi pembimbingan dan pelatihan yang dilakukan oleh pengawas ternyata menujukan hasil yang positif dari pihak sekolah, guru maupun siswa [7].

Evaluasi dampak dari pengawasan adalah sepertti berikut ini. Pengawas sekolah belum sepenuhnya dapat meningkatkan profesionalisme guru [1,8] dan peningkatan kinerja Guru Sekolah Dasar [3]; Pada pihak sekolah berdampak pada penataan administrasi, pihak guru terjadi peningkatan profesionalisasi dalam hal perencanaan, pelaksanaan serta evaluasi hasil belajar dan siswa nampak pada keberhasilan pada prestasi siswa semakin meningkat dari waktu ke waktu [7]. Pada akhirnya dampak pengawasan juga terkait dengan hasil kerja pengawas dalam melaksanakan tugasnya meliputi kesetiaan, prestasi kerja, tanggung jawab, ketaaatan, kejujuran, kerja sama, prakarsa dan kepemimpinan [9].

Tabel 3

Kendala dan faktor pendukung yang dihadapi pengawas sekolah dalam melaksanakan tugas dan fungsinya

No Kendala dan faktor pendukung yang dihadapi pengawas sekolah

1 Pelaksanaan supervisi dilakukan pengawas secara singkat, karena keterbatasan waktu. 


\begin{tabular}{|c|c|}
\hline & $\begin{array}{l}\text { Selain itu, pengawas belum membuat perencanaan yang lebih baik; } \\
\text { Adapun faktor penghambat pelaksanaan suvervisi yang dilakukan oleh pengawas yaitu } \\
\text { kurangnya kemampuan pengawas sekolah dalam menyusun program supervise. Selain } \\
\text { itu, tenaga pengawas yang tidak sesuai dengan masing-masing bidang studi sehingga } \\
\text { supervisi yang dilaksanakan belum memberikan pengaruh yang besar dalam } \\
\text { peningkatan profesionalguru. Kondisi ini juga terjadi, karena Kabupaten Pidie Jaya } \\
\text { masih dalam tahap pengembangan di segala bidang termasuk di bidang pendidikan. } \\
\text { Faktor Pendukung pelaksanaan supervisi oleh pengawas yaitu kehadiran pengawas } \\
\text { membuat para guru termotivasi dalam melaksanakan program pembelajaran, adanya } \\
\text { motivasi guru untuk belajar membuat RPP dengan baik dan melatih berbagai metode } \\
\text { mengajar. }\end{array}$ \\
\hline 2 & $\begin{array}{l}\text { Hambatan yang dialami pengawas dalam supervisi akademik adalah kurangnya tenaga } \\
\text { pengawas PAI, banyaknya guru yang harus dibina dan kurangnya intensitas supervisi. } \\
\text { Solusi dari kendala tersebut adalah rekrutmen pengawas baru, peningkatan intensitas } \\
\text { supervisi kunjungan kelas dan peningkatan program pembinaan supervisi pengawas } \\
\text { secara berkala dan berkesinambungan. }\end{array}$ \\
\hline 3 & $\mathrm{Na}$ \\
\hline 4 & $\begin{array}{l}\text { Kendala dalam pelaksanaan supervisi akademik pengawas adalah ketidaksesuaian latar } \\
\text { belakang pendidikan antara pengawas dan guru bahasa Arab. } \\
\text { Kendala kepala madrasah dalam melaksanakan supervisi akademik adalah } \\
\text { ketidaksesuaian kualifikasi akademik supervisor dengan guru bahasa Arab. }\end{array}$ \\
\hline 5 & $\begin{array}{l}\text { Dalam kasus di Kota Jayapura, satu orang pengawas harus melakukan pengawasan } \\
\text { terhadap } 16 \text { Sekolah Menengah Atas sehingga kinerjanya kurang maksimal. }\end{array}$ \\
\hline 6 & $\begin{array}{l}\text { Hasil evaluasi juga menunjukan kendala yang dihadapi pengawas antara lain: (a) } \\
\text { minimnya pengetahuan dan keterampilan teknologi informasi oleh pengawas, (b) } \\
\text { kondisi geografis di wilayah kota tidore kepulauan serta belum memadainya sarana dan } \\
\text { prasarana umum, (c) minimnya sarana prasarana pendukung yang diberikan kepada } \\
\text { pengawas, serta ketidakjujuran dan kurangnya penyampaian informasi oleh guru } \\
\text { maupun kepala sekolah kepada pengawas sekolah saat pengawasan berlangsung. }\end{array}$ \\
\hline 7 & $\begin{array}{l}\text { Evaluasi pelaksanaan program pengawas secara langsung belum bisa memenuhi } \\
\text { standar evaluasi dan monitoring yang dilaksanakan oleh pengawas baik secara periodik } \\
\text { atau kontinyu sesuai dengan lembar kerja pengawas. } \\
\text { Masih terdapat beberapa kekurangan yang menjadi perhatian umum yakni pelaksanaan } \\
\text { kunjugan ke sekolah belum sesuai dengan jadwal yang telah ditetapkan. }\end{array}$ \\
\hline 8 & $\mathrm{Na}$ \\
\hline 9 & $\mathrm{Na}$ \\
\hline
\end{tabular}

Belum maksimalnya hasil dan dampak supervisi oleh pengawas sehingga belum bisa memenuhi standar ternyata terkait dengan banyaknya kekurangan dan/kendala dalam pelaksanaannya. Adapun faktor penghambat pelaksanaan suvervisi yang dilakukan oleh pengawas yaitu kondisi geografis (di wilayah kepulauan) serta belum memadainya sarana dan prasarana umum [6], kurangnya tenaga pengawas, banyaknya guru yang harus dibina dan kurangnya intensitas supervisi [2]; satu orang pengawas harus melakukan pengawasan terhadap 16 Sekolah Menengah Atas [5], kurangnya tenaga pengawas, banyaknya guru yang harus dibina dan kurangnya intensitas supervisi [3] sehingga pelaksanaan kunjugan ke sekolah belum bisa sesuai dengan jadwal yang telah ditetapkan [7]. Kurangnya kemampuan pengawas sekolah dalam menyusun program supervise; Selain itu, tenaga pengawas yang tidak sesuai dengan masingmasing bidang studi [1], ketidaksesuaian latar belakang pendidikan antara pengawas dan guru [4]. Kendala yang lain: (a) minimnya pengetahuan dan keterampilan teknologi 
informasi oleh pengawas, (b) minimnya sarana prasarana pendukung yang diberikan kepada pengawas, serta ketidakjujuran dan kurangnya penyampaian informasi oleh guru maupun kepala sekolah kepada pengawas sekolah saat pengawasan berlangsung [6].

Faktor Pendukung pelaksanaan supervisi oleh pengawas yaitu kehadiran pengawas membuat para kepala sekolah dan guru termotivasi dalam melaksanakan program pembelajaran, adanya motivasi guru untuk belajar membuat RPP dengan baik dan melatih berbagai metode mengajar, dan lain lain. [1].

\section{PENUTUP}

Berdasarkan paparan hasil seperti tersaji di atas, maka dapatlah disimpulkan seperti berikut ini.

Langkah supervisi yang dilakukan oleh pengawas sekolah seperti berikut ini; Ternyata ada 2 versi pengawas dalam melaksanakan pengawasan terhadap sekolah binaan baik terhadap kepala sekolah maupun guru: tidak terprogram dan telah terprogram, walaupun begitu belum ada program tindak lanjut. Dalam menyusun program supervisi bagi sekolah binaan, terdapat pengawas yang bekerja sama dengan kepala sekolah binaan, dengan demikian akan terdapat variasi program supervisi pengawas di sekolah satu dengan yang lainnya. Program supervisi yang disusun memperhatikan visi, misi dan tujuan sekolah binaan. Dalam penyusunan program supervisi, para pengawas mendasarkan Peraturan Menteri Pendidikan Nasional Republik Indonesia Nomor 12 Tahun 2007. Program supervisi yang disusun terdiri dari 2 komponen, yaitu supervisi akademik/pengajaran dan supervisi manajejerial; disamping itu ada pengawas yang melakukan pembimbingan dan pelatihan profesional guru dan kepala sekolah berprestasi. Pelaksanaan supervisi yang mendasarkan prencanaan/ program yang telah disusun (meliputi tahap persiapan, pelaksanaan, dan penilaian/pelaporan) sudah dilaksanakan secara baik sesuai aturan dan pedoman yang ada. Jenis kegiatannya adalah pembuatan program, pelaksanaan program, penilaian/ pelaporan, dan rencana tindak lanjut. Teknik yang digunakan pengawas sekolah berupa teknik individual (kunjungan dan observasi kelas, pertemuan/percakapan individual), dan teknik kelompok (mengikutsertakan guru-guru dalam MGMP, workshop, diklat, seminar, dan rapat guru). Evaluasi program pengawasan diperoleh hasil yang bervariasi, mulai dari sedang sampai menujukan hasil yang positif. Evaluasi program supervisi dilakukan oleh Koordinator Pengawas Dinas Pendidikan Pemuda dan Olahraga Kota. Hasil penilaian secara khusus dituangkan dalam DP3. Penilaian dilakukan berdasarkan hasil kerja pengawas dalam melaksanakan tugasnya meliputi kesetiaan, prestasi kerja, tanggung jawab, ketaaatan, kejujuran, kerja sama, prakarsa dan kepemimpinan.

Hasil pengawasan bagi guru dalam peningkatan mutu pendidikan adalah: evaluasi program supervisi menyangkut perencanaan, pelaksanaan maupun hasil bahkan dampak program. Evaluasi terhadap perencanaan supervisi (kecuali yang tidak menyusun program) adalah: penyusunan program pengawasan memperoleh nilai baik, 
Evaluasi penyusunan program pengawas dilaksanakan sangat efektif sesuai dengan perencanaan program supervisi yakni melakukan pengawasan setiap semesteran, triwulan dan bulanan. Evaluasi pelaksanaan supervisi (bagi pengawas yang telah menyusun program), mulai dari kategori rendah, sampai berprestasi amat baik, sudah dilaksanakan secara baik sesuai dengan aturan dan pedoman yang ada setiap pengawas, (walau masih terdapat beberapa kekurangan seperti pelaksanaan kunjugan ke sekolah belum sesuai dengan jadwal, belum memenuhi standar evaluasi dan monitoring). Evaluasi terhadap hasil supervisi bervariasi mulai dari yang masih belum maksimal/ kategori rendah, berprestasi sedang sampai efektif, yang nampak dengan meningkatnya kompetensi pedagogik guru (penguasaan guru terhadap teori belajar dan prinsip pembelajaran, efektivitas guru dalam pembelajaran yang mendidik, dan fasilitasi pengembangan potensi peserta didik) dan kompetensi profesional. Evaluasi dampak dari pengawasan adalah: peningkatan kinerja profesionalisasi guru dan penataan administrasi, peningkatan dalam hal perencanaan, pelaksanaan serta evaluasi hasil belajar dan peningkatan hasil/prestasi belajar siswa. Dampak pengawasan juga terkait dengan hasil kerja pengawas dalam melaksanakan tugasnya meliputi kesetiaan, prestasi kerja, tanggung jawab, ketaaatan, kejujuran, kerja sama, prakarsa dan kepemimpinan. walaupun begitu ada juga pengawas sekolah yang belum sepenuhnya dapat meningkatkan profesionalisme guru.

Kendala yang dihadapi pengawas sekolah dalam melaksanakan tugas dan fungsinya ada yang rterkait dengan kondisi geografis serta belum memadainya sarana dan prasarana umum, kurangnya tenaga pengawas, banyaknya guru yang harus dibina dan kurangnya intensitas supervisi (misalnya satu orang pengawas harus melakukan pengawasan terhadap 16 SMA). Kurangnya kemampuan pengawas sekolah dalam menyusun program supervisi, kualifikasi pengawas yang tidak sesuai dengan kualifikasi guru masing-masing masing-masing bidang studi, minimnya pengetahuan dan keterampilan TIK oleh pengawas, minimnya sarana prasarana pendukung, serta ketidak-jujuran dan kurangnya penyampaian informasi oleh guru maupun kepala sekolah kepada pengawas sekolah saat pengawasan berlangsung. Faktor Pendukung pelaksanaan supervisi oleh pengawas yaitu kehadiran pengawas membuat para kepala sekolah dan guru termotivasi dalam melaksanakan program pembelajaran, adanya motivasi guru untuk belajar membuat RPP dengan baik dan melatih berbagai metode mengajar, dan lain lain.

\section{DAFTAR PUSTAKA}

Aripin. 2011. Perkembangan Supervisi Pendidikan. http://aripinmuslim.blogspot.co.id/ 2011/04/perekembangan-supervisi-pendidikan.html

Bang Mohtar. 2012. Tesis Bab I s.d. V dan Lampiran 1 s.d. http://www.slideshare.net/ bangmohtar/tesis-bab-i-sd-v-dan-lampiran-1-sd

Dewi Novrita, 2014. Maksimalisasi Peran Pengawas Sekolah Menengah Atas Dalam Meningkatkan Profesionalisme Guru PAI Studi Kasus Pada Kementerian Agama di Kota Jayapura, Papua. Sekolah Tinggi Agama Islam Negeri (STAIN) Al Fatah Jayapura, Papua. 
Diaz, W. 2015. Kontribusi Partisipasi Guru Dalam Kelompok Kerja Guru (KKG) dan Intensitas Supervisi Akademik Oleh Pengawas Terhadap Kinerja Guru Sekolah Dasar Se-Kecamatan Kotagede Yogyakarta (Doctoral dissertation, Universitas Negeri Yogyakarta).

Direktorat Tenaga Kependidikan Dirjen Peningkatan Mutu Pendidik dan Tenaga Kependidikan. 2007. Naskah Materi Diklat Pembinaan Kompetensi untuk Calon Kepala Sekolah/ Kepala Sekolah. Jakarta: Depdiknas.

Hardja Sapoetra. 2010. Supervisi Pendidikan (Administrasi dan Supervisi Pendidikan). http://hardjasapoetra.blogspot.co.id/2010/03/supervisi-pendidikanadministrasi-dan.html

Ihsanuddin, A. 2015. Implementasi Supervisi Pengawas Pai Dalam Meningkatkan Kompetensi Pedagogik Guru PAI SD di Kecamatan Berbah Sleman (Doctoral dissertation, IAIN Surakarta).

Imam Gozali. 2011. Prosedur Pengembangan Sistem Supervisi Pendidikan. http://pujakesuma-igmafazizah.blogspot.co.id/2011/10/prosedurpengembangan-sistem-supervisi.html

Makmurrizal, C. Z. H., \& Ibrahim, S. 2016. Pelaksanaan Supervisi Oleh Pengawas Sekolah Dalam Meningkatkan Kompetensi Rofesionalisme Guru Pada SMA Negeri 2 Bandar Baru Pidie Jaya. Jurnal Administrasi Pendidikan: Program Pascasarjana Unsyiah, 4(3)

Masaong, A.K. 2013. Supervisi Pengajaran dan Pengembangan Kapasitas Guru. Bandung: Penerbit Alfabeta.

Mintarsih Danumihardja. 2009. Pengelolaan Pendidikan dan Profesi Tenaga Kependidikan. http://miendanu.blogspot.co.id/2009_07_01_archive.html

Mintarsih Danumihardja. 2009. Supervisi Pendidikan. http://tenaga-kependidikan. blogspot.co.id/2009/03/supervisi-pendidikan.html

Muhammad, N. 2013. Manajemen Pengawas Dalam Pelaksanaan Supervisi Pendidikan Anak Usia Dini Di Kota Banda Aceh. (Doctoral dissertation).

Olivia, Peter F. 1984. Supervision for Today's School. New York: Longman.

Rivai, M.A. 1981. Administrasi dan Supervisi Pendidikan. Bandung: Yenmars.

Ruzi Rahmawati. 2012. Program Supervisi Pendidikan dan Program Pembinaan Guru. http://ruzirahmawati.blogspot.co.id/2012/03/program-supervisi-pendidikandan.html

Sagala, H.S. 2000. Administrasi Pendidikan Kontemporer. Bandung: Alfabeta.

Saleh, L., \& Sumar, W. T. 2013. Evaluasi Program Pengawas di SDN Se Kecamatan Telaga Biru Kabupaten Gorontalo. KIM Fakultas Ilmu Pendidikan, 1(1).

Satori, Djam'an. 1997. Supervisi Akademik (Teori dan Praktek). Jakarta: Depdikbud.

Shokhikhah, N. I., \& PD, S. 2015. Pelaksanaan Supervisi Akademik Terhadap Guru Bahasa Arab (Studi Kasus di MTs Negeri Parakan Temanggung) (Doctoral dissertation, UIN Sunan Kalijaga Yogyakarta).

Sudjana, Nana, dkk. 2006. Standar Mutu Pengawas. Jakarta: Dirjen PMPTK Direktorat Tenaga Kependidikan Depdiknas. 
Suhardan, Dadang. 2010. Supervisi Profesional: Layanan dalam Meningkatkan Mutu Pembelajaran di Era Otonomi Daerah. Bandung: Alfabeta.

Suliadi, R. 2009. Hubungan Antara Supervisi Pengawas Sekolah, Inten-sitas Kegiatan MGMP dan Motivasi Berprestasi Guru dengan Profesi-nalisme Guru SMA Negeri di Kota Malang.(Tesis). Disertasi dan Tesis Program Pascasarjana $U M$.

Syawal, J., \& Kartowagiran, B. 2015. Evaluasi Kinerja Pengawas Sekolah Dalam Melakukan Supervisi Penyelenggaraan Pendidikan SD di Kota Tidore Kepulauan. Jurnal Evaluasi Pendidikan, 1(2), 208-222. 